\title{
Bats of a varzea forest in the estuary of the Amazon River, state of Amapá, Northern Brazil
}

\author{
Isai Jorge de Castro ${ }^{1,2,4}$ \& Fernanda Michalski, ${ }^{1,3}$ \\ ${ }^{1}$ Universidade Federal do Amapá, Programa de Pós-Graduação em Biodiversidade Tropical, Macapá, AP, Brazil. \\ ${ }^{2}$ Instituto de Pesquisas Científicas e Tecnológicas do Estado do Amapá, Macapá, AP, Brazil. \\ ${ }^{3}$ Instituto para a Conservação dos Carnívoros Neotropicais, Atibaia, SP, Brazil. \\ ${ }^{4}$ Corresponding author: Isai Jorge de Castro,e-mail: isai.j.castro@gmail.com
}

CASTRO, I.J., MICHALSKI, F. Bats of a varzea forest in the estuary of the Amazon River, state of Amapá, Northern Brazil. Biota Neotropica. 15(2): e20140168. http://dx.doi.org/10.1590/1676-06032015016814

\begin{abstract}
The varzea forests of the estuary of the Amazon River cover 25,000 $\mathrm{km}^{2}$ within the states of Pará and Amapá. The mammals of those forests, especially bats, are still poorly known. Hence, the present study aimed at inventorying the bat species from three localities of a varzea forest in the estuary of the Amazon River. Between November and December 2013, we selected 18 sampling sites in the mouths of three tributaries of the Amazon River: the rivers Ajuruxí, Maracá, and Mazagão. We set up ten mist nets $(12 \times 3 \mathrm{~m})$ along a 150 -m linear transect in each sampling site, in a total sampling effort of $38,888 \mathrm{~m}^{2} . \mathrm{h}$. We captured 403 individual bats of 40 species and five families. We recorded the families: Phyllostomidae $(\mathrm{n}=31$ species), Emballonuridae $(\mathrm{n}=6$ species $)$, Moormopidae $(\mathrm{n}=1$ species $)$, Vespertilionidae ( $\mathrm{n}=1$ species), and Thyropteridae $(\mathrm{n}=1$ species). Carollia perspicillata, Artibeus planirostris, and Carollia brevicauda comprised $45 \%$ of the records. We also made the first record of Glyphonycteris daviesi for Amapá state, and captured rare species, such as Dicludurus albus and Macrophyllum macrophylum. Our results show that the varzea forest of the estuary of the Amazon River harbors high bat diversity, and, hence, conservation policies should be considered for the region. Those policies should encourage the responsible management of açai palm (Euterpe oleracea) and timber. They should also fight illegal timber exploitation that threatens the fauna and flora of those biodiverse forests. Keywords: Chiroptera, conservation, biodiversity, floodable forest.
\end{abstract}

CASTRO, I.J., MICHALSKI, F. Morcegos de floresta de várzea no estuário do Rio Amazonas, estado do Amapá, Norte do Brasil. Biota Neotropica. 15(2): e20140168. http://dx.doi.org/10.1590/1676-06032015016814

Resumo: As florestas de várzea do estuário do Rio Amazonas ocupam uma extensão $25.000 \mathrm{~km}^{2}$, abrangendo os estados do Pará e Amapá. Os mamíferos destas florestas, especificamente morcegos ainda são pouco conhecidos. Este estudo visa apresentar uma lista de espécies de morcegos de três localidades em floresta de várzea no estuário do Rio Amazonas, contribuindo assim com o conhecimento da quiropterofauna desta fitofisionomia. Entre Novembro e Dezembro de 2013 foram selecionados 18 sítios de coletas na foz de três rios tributários do Rio Amazonas: Rio Ajuruxí, Rio Maracá e Rio Mazagão. Com o uso de dez redes de neblina $(12 \times 3 \mathrm{~m})$ armadas ao longo de um transecto linear de 150 metros em cada sitio de coleta e totalizando um esforço amostral de $38,888 \mathrm{~m}^{2}$. h capturamos 403 indivíduos distribuídos em 40 espécies e cinco famílias. As famílias registradas foram Phyllostomidae $(\mathrm{n}=31$ espécies $)$, Emballonuridae ( $n=6$ espécies), Moormopidae $(n=1$ espécie), Vespertilionidae $(n=1$ espécie) e Thyropteridae ( $\mathrm{n}=1$ espécie). Carollia perspicillata, Artibeus planirostris e Carollia brevicauda compreenderam $45 \%$ dos registros. Nós documentamos o primeiro registro de Glyphonycteris daviesi para o estado do Amapá. Registramos também espécies raras como Dicludurus albus e Macrophyllum macrophylum. Os dados obtidos neste estudo revelam que as florestas de várzea do estuário do Rio Amazonas abrigam uma alta riqueza e diversidade de morcegos e que politicas de conservação devem ser consideradas para a manutenção desta diversidade. Tais politicas devem ser focadas no incentivo para o manejo responsável do cultivo do açaizeiro (Euterpe oleracea) e da exploração da madeira, além da redução da exploração madeireira ilegal que causa prejuízos a fauna e flora dessas florestas ricas em biodiversidade.

Palavras-chave: Chiroptera, conservação, biodiversidade, floresta inundável.

\section{Introduction}

Varzea forests are subjected to the seasonal flood of white-waters rivers with neutral $\mathrm{pH}$, which carry high load of sediments and nutrients, such as the rivers Amazon, Purus, and Juruá (Prance 1979, Sioli 1984). They cover an area of $200,000 \mathrm{~km}^{2}$ in the Amazon River Basin (Junk 1984, Wittmann et al. 2010). In the estuary of the Amazon River, varzea forests 
cover an area of approximately $25,000 \mathrm{~km}^{2}$, within the states of Pará and Amapá, Eastern Amazon (Lima et al. 2001). In this region of the Amazon, large areas have been altered due to the large demand for timber and cultivation of açai palm (Euterpe oleracea Mart.,1824), which are among the products of highest economical importance in the varzea of the Amazon estuary (Muñiz-Miret et al. 1996, Queiroz \& Mochiutti 2001, Brondízio et al. 2002, Weinstein \& Moegenburg 2004, Homma 2012). Therefore, biodiversity maintenance in varzea forests depends mainly on the knowledge and conservation of the species that inhabit them.

Bats are a diverse and abundant group of mammals, which, depending on the region, can represent $60 \%$ of the local fauna (Simmons \& Voss 1998). Bats play several roles in the regulation of tropical ecosystems: they are responsible for the seed dispersal of over 500 plant species, for the pollination of angiosperms, and for the control of insect population, which includes agricultural pests and disease vectors (Medellín et al. 2000, Jones et al. 2009, Kunz et al. 2011). The bat fauna of Brazil is very expressive: out of 701 mammal species currently known in the country (Paglia et al. 2012), at least 178 are bats (Nogueira et al. 2014). In the Brazilian Amazon, 147 bat species of nine families are recorded (Bernard et al. 2011, Castro et al. 2012). In Amapá, 86 bat species of eight families are recorded (Martins et al. 2006, Martins et al. 2011, Silva et al. 2013), but most inventories were concentrated in nonflooded plateau forests (locally known as terra firme forests).

In the past ten years, the number of bat studies in floodable forests of the Brazilian Amazon increased considerably, in particular studies on bat ecology, but they were concentrated in Central Amazon, in the state of Amazonas (Ramos Pereira et al. 2009, Ramos Pereira et al. 2010a, Ramos Pereira et al. 2010b, Marques et al. 2012, Bobrowiec et al. 2014). However, the varzea forests in the estuary of the Amazon River, Eastern Amazon, are still poorly known for bats. Only two studies were carried out in this part of the Amazon: one in the Marajó Region, in Anajás (Marques-Aguiar et al. 2002), and the other in the surroundings of Belém (Kalko \& Handley Jr. 2001), both in the state of Pará. Taking into account the need for studies on the bat fauna in varzea forests, a bat inventory would be an important tool for decision-making in the management of those environments (Silveira et al. 2010). Hence, the present study aimed at inventorying the bat species from three localities of a varzea forest in the estuary of the Amazon River.

\section{Material and Methods}

The study area is located in the municipality of Mazagão, southeastern Amapá State, northern Brazil. This region is located within the estuary of the Amazon River. The vegetation is classified as alluvial dense rainforest (IBGE 2004), which is popularly known as varzea forest (Figure 1). The forests of the estuary of the Amazon River have a peculiarity: due to the closeness to the Atlantic Ocean, water level peaks are regulated by the tides, and the forests are flooded twice a day. The climate of the region is equatorial humid and the average temperature is $26^{\circ} \mathrm{C}$, with annual rainfall around $2,000 \mathrm{~mm}$ (SUDAM 1984).

We selected 18 sampling sites (Figure 1, Table1) in the mouth of three tributaries of the Amazon River: Ajuruxí, Maracá, and Mazagão. In each tributary, we selected six sampling sites, with a minimum distance of $1 \mathrm{~km}$ among them.
In the study area, the economical activities are centered in plant extractivism, mainly of the açai palm (Euterpe oleracea), with managed areas varying from 1 to 20 ha per family. There is also timber exploitation; timber processing is carried out in local family sawmills that supply local communities and the municipalities of Macapá and Santana, state of Amapá.

Bats were captured with mist nets set up along a $150-\mathrm{m}$ linear transect in each sampling site between November and December 2013. In each sampling night, we set up 10 nets $(12 \times 3 \mathrm{~m})$, which were opened at sunset, checked at intervals of 20-30 min, and closed after six hours of exposure. Species identification was made using an identification key for bats of the subregion of the Guiana (Lim \& Engstrom 2001) and identification keys for the bats of South America (Gardner 2008). For identification, we took biometrical measurements, such as weight (with a spring scale) and forearm length (with a digital caliper). We also recorded sex, age, and reproductive status. Nomenclature followed Nogueira et al. (2014) except for recognizing Pteronotus rubiginosus rather than Pteronotus parnellii for French Guiana and Amapá State in Brazil (Thoisy et al. 2014). Bats were classified into broad foraging guilds based on published feeding habits, following Gardner (1977) for Phyllostomidae and Willig (1986) for all other families. A maximum of six vouchers of each species were collected, with a permit from SISBIO (40774-1). The vouchers were fixed in formalin at $10 \%$, preserved in alcohol $70 \%$, and deposited in the Animal Collection of Amapá, at the Institute of Scientific and Technological Research of Amapá (IEPA), Macapá, under the numbers IEPA 3926 and IEPA 3953-4013.

The total sampling effort of $38,888 \mathrm{~m}^{2}$.h was calculated by multiplying the area of each net by the exposure time, number of nights, and number of nets (following Straube \& Bianconi 2002). Rarefaction curves were built based on the number of individuals and species to test for the sufficiency of the sampling effort (Gotelli \& Colwell 2001). To estimate bat richness we used the non-parametrical estimator Jackknife I (Magurran 2004). We estimated species diversity with Shannon index (H'). This index is considered mainly a measurement of dominance, as it gives higher weight to common species (Magurran 2004). Rarefaction curves and the calculation of Jackknife I and Shannon index (H') were made in R 3.0.1 (R Development Core Team 2013).

\section{Results}

We captured 403 individual bats of 40 species and five families, considering the whole study area. The families recorded were: Phyllostomidae ( $\mathrm{n}=31$ species), Emballonuridae ( $\mathrm{n}=6$ species), Moormopidae ( $\mathrm{n}=1$ species), Vespertilionidae ( $\mathrm{n}=1$ species), and Thyropteridae ( $\mathrm{n}=1$ species) (Table 2 ). Nine species were captured exclusively in the mouth of the Ajuruxi River, six in the mouth of the Maracá River, and only three species were exclusive to the mouth of the Mazagão River (Table 2). All species are classified as Least Concern by IUCN (2014), except Platyrrhinus fusciventris and $P$. incarum which have not yet been evaluated.

The family Phyllostomidae was largely dominant, with $76.92 \%$ of the species and $95 \%$ of the individual bats collected. Carollia perspicillata (96 individuals), Artibeus planirostris (47 individuals), and Carollia brevicauda (39 individuals) comprised $45 \%$ of the records. Emballonuridae was the second family in number of species $(15 \%)$ and individuals $(3.5 \%)$, and included rare species, such as Peropteryx leucoptera, collected 


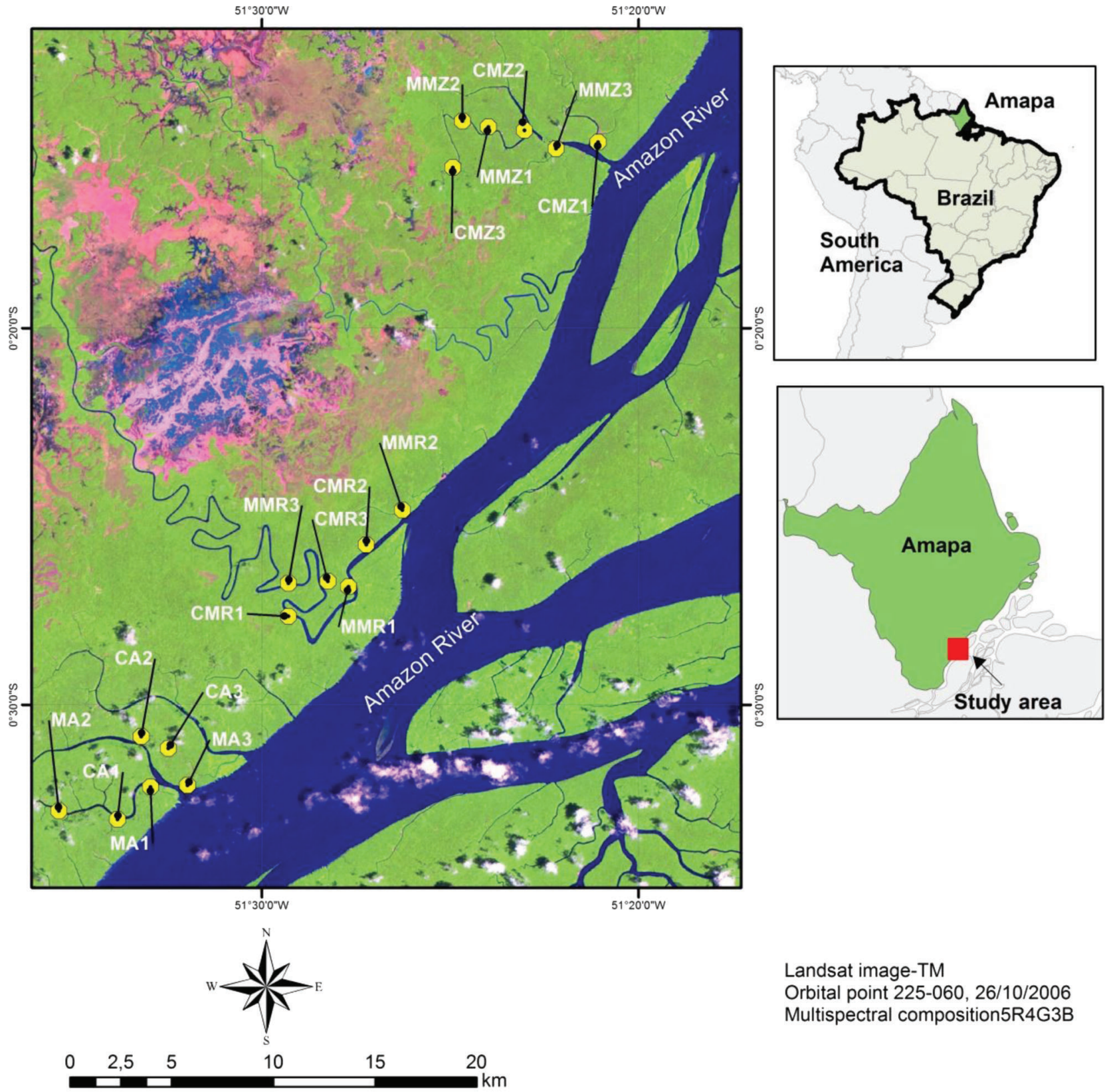

Exec.: Castro, 2014

Figure 1. Location of the study area. Yellow points are the sampling sites at the mouths of the rivers Ajuruxi (MA1, MA2, MA3, CA1, CA2, CA3), Maracá (MMR1, MMR2, MMR3, CRM1, CRM2, CRM3), and Mazagão (MMZ1, MMZ2, MMZ3, CMZ1, CMZ2, CMZ3).

Figura 1. Localização da área de estudo. Pontos em amarelo são os sítios de coleta, sendo Foz do Rio Ajuruxi (MA1, MA2, MA3, CA1, CA2, CA3), Foz do Rio Maracá (MMR1, MMR2, MMR3, CRM1, CRM2, CRM3) e Foz do Rio Mazagão (MMZ1, MMZ2, MMZ3, CMZ1, CMZ2, CMZ3).

in the mouth of the Mazagão River, and Diclidurus albus and Cormura brevirostris collected in the mouth of the Maracá River (Table 2).

Based on the 40 species sampled, the Jacknife 1 estimator points that approximately 53 bat species occur in the study area. Hence, we recorded $75 \%$ of the expected local bat species. Rarefaction curves did not show signs of stabilization, which indicates that more species should be added to the list of the studied varzea forests (Figure 2).

In the present study, we made the first record of Glyphonycteris daviesi (collection accession number IEPA 3962) for the state of Amapá. The record was made at 19:00 on November 27, 2013, at the mouth of the Ajuruxi River, Cajari Reserve, locality of Vila Maranata. The environment where G. daviesi was collected is a managed açai palm forest (Euterpe oleracea), with an unobstructed understory and large hollow trees, with the predominance of Pracuúba (Mora paraensis), which may provide roosts for $G$. daviesi.

The trophic structure of the bat assemblage of the three localities studied in the estuary of the Amazon River was composed of frugivores, aerial insectivores, gleaning animalivores, and sanguivores. Frugivorous bats were more abundant 
Table 1. Sampling sites, geographical coordinates, number of bats species and individuals sampled in a varzea forest in the estuary of the Amazonas River. In each site were used 10 mist nets with a sampling effort of $2160 \mathrm{~m}^{2} . \mathrm{h}$ per site.

Tabela 1. Sítios de coleta, coordenadas geográficas, número espécies de morcegos e de indivíduos amostrados em floresta de várzea no estuário do Rio Amazonas. Em cada sítio foram usadas 10 redes de neblina com um esforço amostral de $2160 \mathrm{~m}^{2}$.h por sítio.

\begin{tabular}{|c|c|c|c|c|c|}
\hline Site & River & Latitude & Longitude & Species & \# ind. \\
\hline CA1 & Ajuruxi & -0.550726 & -51.563764 & 5 & 5 \\
\hline CA2 & Ajuruxi & -0.514091 & -51.553349 & 15 & 44 \\
\hline CA3 & Ajuruxi & -0.519318 & -51.541283 & 11 & 18 \\
\hline MA1 & Ajuruxi & -0.536379 & -51.54919 & 16 & 38 \\
\hline MA2 & Ajuruxi & -0.546935 & -51.589648 & 8 & 13 \\
\hline MA3 & Ajuruxi & -0.535683 & -51.532811 & 8 & 15 \\
\hline MMR 1 & Maracá & -0.447744 & -51.461611 & 15 & 34 \\
\hline MMR2 & Maracá & -0.413852 & -51.437795 & 12 & 28 \\
\hline MMR3 & Maracá & -0.446273 & -51.488222 & 11 & 32 \\
\hline CMR1 & Maracá & -0.460856 & -51.488209 & 10 & 20 \\
\hline CMR2 & Maracá & -0.429111 & -51.453823 & 5 & 9 \\
\hline CMR3 & Maracá & -0.445328 & -51.470813 & 7 & 10 \\
\hline CMZ1 & Mazagão & -0.25096 & -51.351336 & 11 & 31 \\
\hline CMZ2 & Mazagão & -0.245761 & -51.383893 & 8 & 20 \\
\hline CMZ3 & Mazagão & -0.2622 & -51.415517 & 12 & 18 \\
\hline MMZ1 & Mazagão & -0.244296 & -51.399837 & 10 & 27 \\
\hline MMZ2 & Mazagão & -0.241649 & -51.411261 & 12 & 18 \\
\hline MMZ3 & Mazagão & -0.253874 & -51.369926 & 11 & 23 \\
\hline
\end{tabular}

than the others, varying from $61 \%$ to $69 \%$ of the captures (Table 2). Gleaning animalivores were the second most frequent foraging guild in the mouths of the rivers Maracá $(26 \%)$ and Ajuruxi (17\%), probably due to higher availability of habitats and food and better habitat conservation (Table 2). The sanguivore bat Desmodus rotundus was captured in all three rivers, but had a higher percentage of capture in the mouth of the Mazagão River. Aerial nectarivorous and insectivorous bats were also more abundant in the mouth of the Mazagão River (Table 2).

The Shannon index $\left(\mathrm{H}^{\prime}\right)$ calculated for the region of the estuary of the Amazon River was $\mathrm{H}^{\prime}=2.91$. The region of the mouth of the Maracá River showed the highest diversity $\left(H^{\prime}=2.75\right)$, followed by the mouth of the Ajuruxi River $\left(H^{\prime}=2.73\right)$, and of the mouth of the Mazagão River $\left(H^{\prime}=2.66\right)$.

\section{Discussion}

The bat species richness and the number of individuals captured in the varzea forests of the estuary of the Amazon River in Amapá (40 species and 403 individuals), was similar to that found in other studies carried out in the Brazilian Amazon (e.g. Martins et al. 2006, 39 species and 470 captures in the Montanhas do Tumucumaque National Park; Ramos Pereira et al. 2009, 43 species and 520 captures in the Amanã Sustainable Development Reserve, considering only records from várzea forest; Bobrowiec et al. 2014, 41 species and 1069 individual captured at lake Uauaçú in the lower Purus River region considering records from varzea and terra firme forests). The bat species recorded in the present study represent approximately $46 \%$ of the species currently known for Amapá (Silva et al. 2013), 27\% of the species known for the Brazilian Amazon (Bernard et al. 2011, Castro et al. 2012) and 22.5\% of the species known for Brazil (Nogueira et al. 2014). Hence, this physiognomy of forest is very important for the maintenance of bat diversity in the Amazon, and, therefore, the economical activity prioritized in this region should be low-impact extractivism.

The high diversity of the bat fauna in the varzea forests was evident from the rarefaction curves, which did not reach an asymptote. This suggests that the sampling effort of $38,888 \mathrm{~m}^{2}$. $\mathrm{h}$ should be increased to obtain a more complete inventory of the varzea forest species in the Amazon estuary. The sampling effort used in our study was moderate compared with other studies conducted in the Amazon that used greater efforts (e.g. Ramos Pereira et al. 2009 used a sampling effort of $54,648 \mathrm{~m}^{2} . \mathrm{h}$ in varzea forest in the Amanã Sustainable Development Reserve, and Bobrowiec et al. 2014 used a total of 72,000 $\mathrm{m}^{2} . \mathrm{h}$ in varzea and terra firme forests in Uauacú lake in the lower Purus River region). The estimate made with Jacknife I (53 species) suggests that we recorded $75 \%$ of the bat species of the study area. The missing species probably belong to the families Molossidae and Vespertilionidae, which are more difficult to capture, because they forage at high altitudes (Voss \& Emmons 1996, Bernard \& Fenton 2003), frequently higher than ground-level mist nets. Species of those families are more frequently captured when mist nets are set in the canopy, when colonies are discovered in households or tree hollows, or when the bats come down to drink water from rivers, lakes, or water holes on the forest edge (Voss \& Emmons 1996).

We also highlight the new record of Glyphonycteris daviesi for the state of Amapá, which was captured in a managed açai palm forest (Euterpe oleracea) in the mouth of the Ajuruxi River, Cajari Reserve. Hence, the number of bat species known for Amapá raises from 86 to 87 (Martins et al. 2006, Martins \& Bernard 2008, Silva et al. 2013). G. daviesi is a rare species, with few individuals deposited in museums (Gregorin \& Rossi 2005). In Brazil it was known only for the states of Pará, Amazonas, Rondônia, and Bahia (Williams \& Genoways 2008). Although this species is classified as "least concern" in the red list of IUCN 2014, in neighbor countries, such as Bolivia, it is classified as vulnerable, mainly due to threats to the montane 
Table 2. Species list, number of captures and trophic guild of the bat species captured in three localities of a varzea forest in the estuary of the Amazon River. Trophic guild categories: AI = aerial insectivore, FR = frugivore, GA = gleaning animalivore, NE = nectarivore, and $\mathrm{SAN}=$ sanguivore.

Tabela 2. Lista de espécies, número de capturas e guilda trófica de morcegos das espécies de morcegos capturadas em três localidades de floresta de várzea no estuário do Rio Amazonas. Para guilda trófica $(\mathrm{AI}=$ aerial insectivore, $\mathrm{FR}=$ frugivore, GA $=$ gleaning animalivore, $\mathrm{NE}=$ nectarivore, $\mathrm{SAN}=$ Sanguivore).

\begin{tabular}{|c|c|c|c|c|c|}
\hline & Ajuruxi & Maracá & Mazagão & Total & Trophic guild \\
\hline \multicolumn{6}{|l|}{ Families/Species } \\
\hline \multicolumn{6}{|l|}{ Emballonuridae } \\
\hline Cormura brevirostris (J. A. Wagner, 1843) & 0 & 1 & 0 & 1 & AI \\
\hline Diclidurus albus (wied-Neuwied, 1820) & 0 & 1 & 0 & 1 & AI \\
\hline Saccopteryx bilineata (Temminck, 1838) & 3 & 0 & 4 & 7 & AI \\
\hline Saccopteryx leptura (Schreber, 1774) & 0 & 1 & 2 & 3 & AI \\
\hline Peropteryx leucoptera W. Peters, 1967 & 0 & 0 & 1 & 1 & AI \\
\hline Peropteryx macrotis (J. A. Wagner, 1843) & 1 & 0 & 0 & 1 & AI \\
\hline \multicolumn{6}{|l|}{ Momoopidae } \\
\hline Pteronotus rubiginosus (Wagner, 1843) & 0 & 0 & 1 & 1 & AI \\
\hline \multicolumn{6}{|l|}{ Phyllostomidae } \\
\hline Artibeus lituratus (Olfers, 1818) & 2 & 0 & 0 & 2 & FR \\
\hline Artibeus obscurus (Schinz, 1821) & 8 & 4 & 5 & 17 & FR \\
\hline Artibeus planirostris (Leach, 1821) & 11 & 20 & 16 & 47 & FR \\
\hline Carollia brevicauda (Schinz, 1821) & 14 & 11 & 14 & 39 & FR \\
\hline Carollia perspicillata (Linnaeus, 1758) & 35 & 29 & 32 & 96 & FR \\
\hline Chrotopterus auritus (W. Peters, 1856) & 2 & 0 & 0 & 2 & GA \\
\hline Choeroniscus minor (W. Peters, 1868) & 2 & 2 & 8 & 12 & $\mathrm{NE}$ \\
\hline Dermanura cinerea Gervais, 1856 & 5 & 3 & 2 & 10 & FR \\
\hline Dermanura gnoma (Handley, 1987) & 1 & 0 & 0 & 1 & FR \\
\hline Desmodus rotundus (É. Geoffroy St.-Hilaire, 1810) & 3 & 6 & 10 & 19 & SAN \\
\hline Glyphonycteris daviesi (Hill, 1965) & 2 & 0 & 0 & 2 & GA \\
\hline Glossophaga soricina (Pallas, 1766) & 4 & 3 & 4 & 11 & $\mathrm{NE}$ \\
\hline Lampronycteris brachyotis (Dobson, 1879) & 1 & 0 & 0 & 1 & GA \\
\hline Lonchophylla thomasi J. A. Allen, 1904 & 6 & 3 & 2 & 11 & $\mathrm{NE}$ \\
\hline Lophostoma silvicolum d'Orbigny, 1836 & 4 & 6 & 3 & 13 & GA \\
\hline Macrophyllum macrophyllum (Schinz, 1821) & 0 & 1 & 0 & 1 & GA \\
\hline Micronycteris hirsuta Peters, 1869 & 5 & 0 & 0 & 5 & GA \\
\hline Micronycteris megalotis (Gray, 1842) & 0 & 3 & 1 & 4 & GA \\
\hline Micronycteris minuta (P. Gervais, 1856) & 0 & 3 & 0 & 3 & GA \\
\hline Micronycteris schmidtorum (Sanborn, 1935) & 1 & 0 & 0 & 1 & GA \\
\hline Phyllostomus elongatus (É. Geoffroy St.-Hilaire, 1810) & 4 & 4 & 3 & 11 & GA \\
\hline Platyrrhinus brachycephalus (Rouk and Carter, 1972) & 0 & 2 & 3 & 5 & FR \\
\hline Plathyrrhinus fusciventris Velazco, Gardner \& Patterson 2010 & 0 & 3 & 4 & 7 & FR \\
\hline Plathyrrhinus incarum (Thomas, 1912) & 0 & 2 & 0 & 2 & FR \\
\hline Rhynophilla pumilio (Peters, 1865) & 7 & 0 & 1 & 8 & FR \\
\hline Tonatia saurophila (Koopman and Williams, 1951 & 4 & 1 & 2 & 7 & GA \\
\hline Trachops cirrhosus (Spix, 1823) & 1 & 9 & 1 & 11 & GA \\
\hline Trinycteris nicefori Sanborn, 1949 & 0 & 8 & 1 & 9 & GA \\
\hline Uroderma bilobatum Peters, 1866 & 4 & 4 & 13 & 21 & FR \\
\hline Vampyriscus bidens (Dobson, 1878) & 2 & 0 & 3 & 5 & FR \\
\hline Vampyrodes caraccioli (Thomas, 1889) & 0 & 2 & 0 & 2 & FR \\
\hline \multicolumn{6}{|l|}{ Thyropteridae } \\
\hline Thyroptera tricolor Spix, 1823 & 0 & 1 & 1 & 2 & AI \\
\hline \multicolumn{6}{|l|}{ Vespertilionidae } \\
\hline Myotis nigricans (Schinz, 1821) & 1 & 0 & 0 & 1 & AI \\
\hline Number of individuals & 133 & 133 & 137 & 403 & \\
\hline Number of species & 26 & 26 & 25 & 40 & \\
\hline Shannon Index (H') & 2.73 & 2.75 & 2.66 & 2.91 & \\
\hline
\end{tabular}

forests and lowland floodable areas where $G$. daviesi occurs (Ochoa \& Velazco 2008). Hence, in Amapá G. daviesi deserves attention in future revisions of endangered species lists, as it was recorded only in varzea forests so far, even after a high sampling effort made in the state (Martins et al. 2006, Martins \& Bernard 2008, Martins et al. 2011, Silva et al. 2013). 

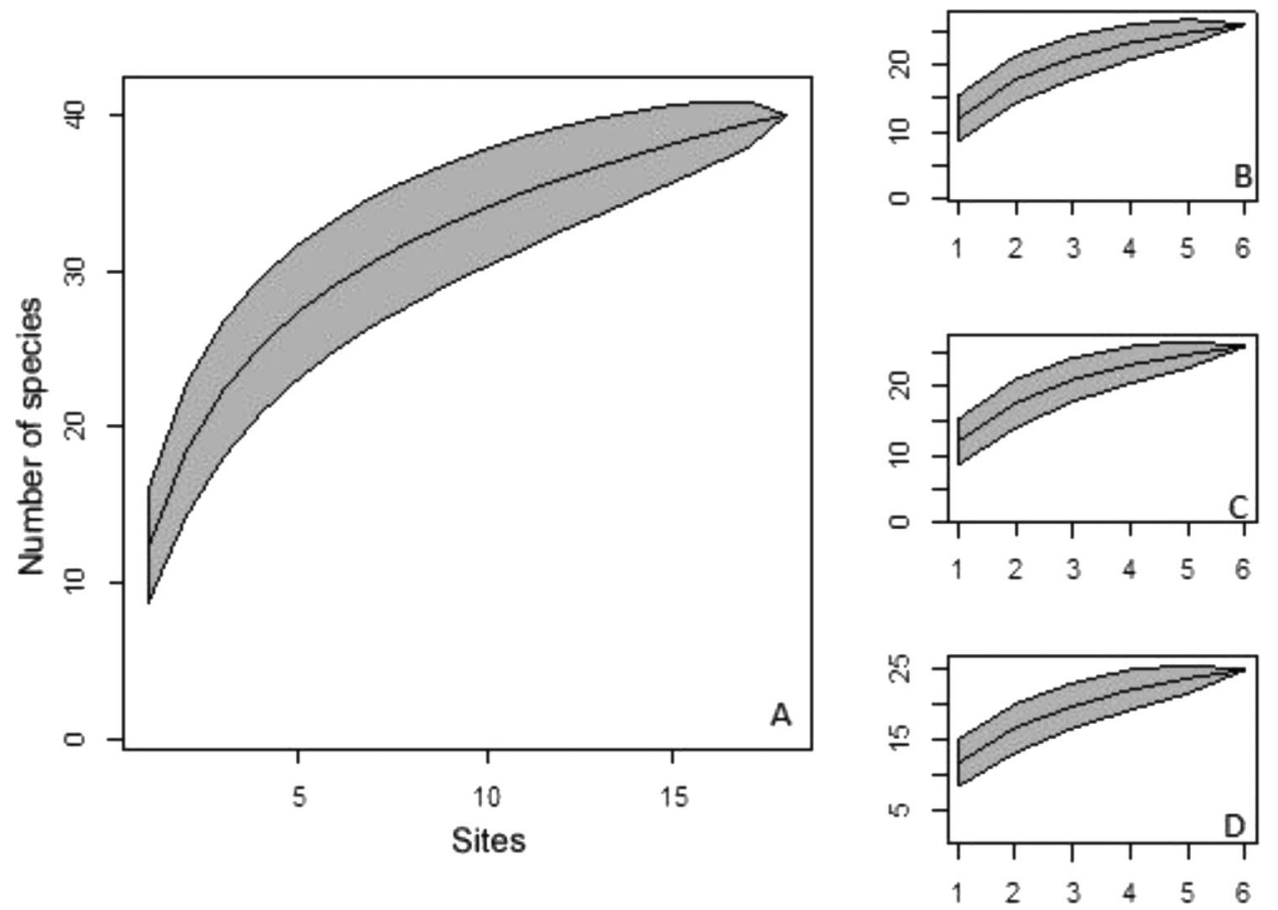

Figure 2. Rarefaction curves for the study area. A: curve for the entire inventory; B = Ajuruxi River, C $=$ Maracá River, D = Mazagão River. Figura 2. Curvas de rarefação para a região de estudo. A: curva para todo o inventário; B = Rio Ajuruxi, C = Rio Maracá, D = Foz do Rio Mazagão.

We found a high abundance of phyllostomid bats, as expected, in particular frugivorous species, such as Artibeus planirostris, which have higher biomass in the varzea forest (várzea) than in terra firme and igapó forests (Ramos Pereira et al. 2010a, Marques et al. 2012). Factors, such as high soil fertility in the varzea forest, allow a larger number of trees to bear fruits throughout the year (Ayres 2006, Haugaasen \& Peres 2006). This could explain the high abundance and biomass of frugivorous bats in this kind of forest.

Gleaning animalivores showed high richness and abundance in the mouth of the rivers Maracá and Ajuruxi. There is a consensus in the literature that these species are sensitive to environmental changes and may be used as bioindicators (Medellín et al. 2000, Soriano \& Ochoa 2001, Presley et al. 2008). Gleaning animalivores feed on arthropods and small vertebrates on the vegetation. In some cases these bats depend on specific roosts, such as termite nests (Kalko et al. 1999, Soriano \& Ochoa 2001, Presley et al. 2008), and any human impact can decrease roost availability. Hence, based on the bat fauna, it is possible to infer that the mouths of the rivers Maracá and Ajuruxi are areas with good environmental integrity.

The sanguivore bat $D$. rotundus was recorded in all three river mouths, but at higher abundance at the Mazagão River. Some authors state that this species is associated with large rivers, which supposedly have higher roost abundance (Lord 1988, Taddei et al. 1991). However, other authors state that the occurrence of $D$. rotundus is more closely linked to food availability, such as farms that raise cattle, horses, and pigs (Wilkinson 1985, Aguiar 2007). The mouth of the Mazagão River meets both requirements: it is close to large rivers, such as the Amazon, and to pig farming areas held by riverine populations. It is common to listen from residents that poultry and pig farming in the region are limited due to attacks by vampire bats (Castro, I. J., pers. comm.). However, this problem can be solved with the adoption of simple measures, such as the use of shelters with protective screens and control of Desmodus populations by health agencies.

Most insectivorous bats found in the present study belong to the family Emballonuridae and were frequent in all three river mouths. These bats prefer illuminated roosts, such as tree trunks close to water bodies (Kunz \& Lumsdem 2003), which are common in varzea forests and favor the occurrence of bats of this family. Two specimens of insectivorous bats (Thyroptera tricolor) of the family Thyropteridae were captured: one at the mouth of the Mazagão River (site MMZ2) and the other at the mouth of the Maracá River (site MMR3), where there is a large amount of plants of the genus Heliconia. Bats of the family Thyropteridae have adhesive disks on their feet and thumbs, which help them attach themselves to leaves of Musa (banana) and Heliconia, which they prefer (Kunz \& Lumsdem 2003).

The data obtained in the present study revealed that the varzea forests of the estuary of the Amazon River harbor high richness and diversity of bats. Therefore, conservation policies should be implemented in the region. Such policies should focus on sustainable management of the açai palm (Euterpe oleracea) and timber exploitation. Illegal timber exploitation, which can threaten the fauna and flora of those biodiversity-rich forests, should also be repressed.

\section{Acknowledgments}

EMBRAPA-Amapá provided us with logistic support to carry out the study; Marcelino Carneiro helped us get support from EMBRAPA. Darren Norris gave invaluable suggestion to this manuscript. Our friends from FLORESTAM, IEPA and UFOPA (Dani, Flavia, Adjalma, Adjard, Jonas, Edglei, 
Ezaquiel, Ramos, Luis Reginaldo, Jadson, Anderson, and Claudia Silva) helped us in the field. FAPEAP -Custeio Tese $\mathrm{n}^{\circ}$ 250.203.055/2013-SETEC and CNPq funded part of the study. CAPES granted I. J. Castro a PhD scholarship.

\section{References}

AGUIAR, L.M.S. 2007. Subfamilia Desmodontinae. In Morcegos do Brasil (Reis, N.R., Peracchi, A.L., Pedro, W. A. \& Lima, I. P. (Eds.). EDUEL, Londrina, pp. 39-43.

AYRES, J.M. 2006. As matas de várzea do Mamirauá. Sociedade Civil Mamirauá, Belém.

BERNARD, E. \& FENTON, M.B. 2003. Bat mobility and roosts in a fragmented landscape in central Amazonia, Brazil. Biotropica 35(2): 262-77

BERNARD, E., TAVARES, V.C. \& SAMPAIO, E. 2011. Compilação atualizada das espécies de morcegos (Chiroptera) para a Amazônia Brasileira. Biota Neotrop.11(1):35-46 http://www.biotaneotropica. org.br/v11n1/pt/abstract?article + bn00611012011 (último acesso em 13/06/2014)

BOBROWIEC, P.E.D., ROSA, L.D.S., GAZARINI, J. \& HAUGAASEN, T. 2014. Phyllostomid Bat Assemblage Structure in Amazonian Flooded and Unflooded Forests. Biotropica 46: 312-321, http://dx.doi.org/10.1111/btp.2014.46.issue-3

BRONDÍZIO, E.S., SAFAR, C.A.M. \& SIQUEIRA, A.D. 2002. The urban market of Açai fruit (Euterpe oleracea Mart.) and rural land use change : Ethnographic insights into the role of price and land tenure constraining agricultural choices in the Amazon estuary. Urban Ecosyst. 6: 67-97, http://dx.doi.org/10.1023/A:1025966613562

CASTRO, I.J., SANTOS, E.R., MARTINS, A.C.M., DIAS, D. \& PERACCHI, A.L., 2012. First record of the pale-winged dog-like bat Peropteryx pallidoptera (Chiroptera: Emballonuridae) for Brazil. Mammalia 76(4): 451-453.

GARDNER, A.L. 1977. Feeding habits. In: Biology of Bats of the New World Family Phyllostomidae. Part II (Baker, R.J, Jones Jr, J.K \& Carter, D.C., Eds.).The Museum, Texas Tech University, Lubbock, pp. 293-350.

GARDNER, A.L. 2008. Mammals of South America, Vol. I. Marsupials, Xenarthrans, Shrews, and Bats. University of Chicago Press, Chicago and London.

GOTELLI, N.J. \& COLWELL, R.K. 2001. Quantifying biodiversity: procedures and pitfall in the measurement and comparison of species richness. Ecol. Lett. 4: 379-391, http://dx.doi.org/10.1046/ j.1461-0248.2001.00230.x

GREGORIN, R. \& ROSSI, R.V. 2005. Glyphonycteris daviesi (Hill, 1964), a rare Central American and Amazonian bat recorded for Eastern Brazilian Atlantic Forest (Chiroptera, Phyllostomidae). Mammalia 69 (3-4):427-430, http://dx.doi.org/10.1515/mamm.2005.035

HAUGAASEN, T. \& PERES, C.A. 2006. Floristic, edaphic and characteristics of flooded and unflooded forests in the lower Rio Purús region of central Amazonia, Brazil. Acta Amazon 36: 25-36.

HOMMA, A.K.O. 2012. Extrativismo vegetal ou plantio: qual a opção para a Amazônia?. Estud. av. 26:167-186, http://dx.doi.org/ 10.1590/S0103-40142012000100012

IBGE - Instituto Brasileiro de Geografia e Estatística. 2004. Mapa de Vegetação do Brasil, $2^{\text {a }}$ edição. Escala 1: 5.000.000.

IUCN. 2014. The IUCN Red List of Threatened Species. Version 2014.1. Available at: htp://www.iucnredlist.org. Accessed on june 13, 2014.

JONES, G., D.S, J., KUNZ, T.H., WILLIG, M.R. \& RACEY, P.A. 2009. Carpe noctem: the importance of bats as bioindicators. Endanger. Species Res. 8: 93-115, http://dx.doi.org/10.3354/esr00182

JUNK, W.J. 1984. Ecology of the várzea floodplain of Amazonian white waterrivers. In The Amazon: Limnology and landscape ecology of a mighty tropical river and its basin (H. Sioli, ed.). Dr. W.J. Junk Publishers, Dordrecht, 216-243.

KALKO, E.K.V., FRIEMEL, D., HANDLEY, C.O. \& SCHNITZLER, H.-U. 1999. Roosting and foraging behavior of two neotropical gleaning bats, Tonatia silvicola and Trachops cirrhosus (Phyllostomidae). Biotropica 31: 344-353.

KALKO, E.K.V. \& HANDLEY Jr., C.O. 2001. Neotropical bats in the canopy: diversity, community structure, and implications for conservation. Plant Ecol. 153:319-333, http://dx.doi.org/10.1023/ A:1017590007861

KUNZ, T. \& LUMSDEM, L. 2003. Ecology of cavity and foliage roosting bats.In Bat Ecology (Kunz, T. H. \& Fenton, M.B, Eds.). The University of Chicago Press, Chicago, pp. 3-90.

KUNZ, T.H., DE TORREZ, E.B, BAUER, D, LOBOVA, T \& FLEMING, T.H. 2011. Ecosystem services provided by bats. Ann. N.Y. Acad. Sci. 1223: 1-38, http://dx.doi.org/10.1111/j.17496632.2011.06004.x

LIM, B.K. \& ENGSTROM, M.D. 2001. Species diversity of bats (Mammalia: Chiroptera) in Iwokrama Forest, Guyana, and the Guianan subregion: implications for conservation. Biodivers. Conserv.10:613-657.

LIMA, R.R., TOURINHO, M.M. \& COSTA, J.P.C. 2001. Várzeas fluvio-marinhas da Amazônia brasileira: Características e possibilidades agropecuárias. Faculdade de Ciências do Pará, Belém.

LORD, R.D. 1988. Control of vampire bats . In Natural History of Vampire Bats (Greenhall, A.M. \& Schmidt, U., Eds.). CRC Press, Florida, pp. 215-226.

MAGURRAN, A.E. 2004. Measuring biological diversity. Blackwell Publishing, Oxford.

MARQUES-AGUIAR, S.A., MELO, C.C.S., AGUIAR, G.F.S. \& QUEIRÓZ, J.A.L. 2002. Levantamento preliminar da mastofauna da região de Anajás-Muaná, Ilha de Marajó, Pará, Brasil Revta bras. Zool. 19: 841-854.

MARQUES, J.T., RAMOS PEREIRA, M.J \& PALMEIRIM, J.M. 2012. Availability of Food for Frugivorous Bats in Lowland Amazonia: The Influence of Flooding and of River Banks. Acta Chiropterol. 14: 183-194, http://dx.doi.org/10.3161/150811012X654862

MARTINS, A.C.M., BERNARD, E. \& GREGORIN, R. 2006. Inventários biológicos rápidos de morcegos (Mammalia, Chiroptera) em três unidades de conservação do Amapá, Brasil. Rev. Bras. Zool. 23: 1175-1184, http://dx.doi.org/10.1590/S0101-81752006000400026

MARTINS, A.C.M. \& BERNARD, E. 2008. Inventários rápidos de morcegos no Parque Nacional Montanhas do Tumucumaque: Resultados das Expedições I a V e Síntese. In Inventários Biológicos Rápidos no Parque Nacional Montanhas do Tumucumaque, Amapá, Brasil (E. Bernard, ed.). RAP Bull. Bio. Assess. Conservation International, Arlington, VA. 48:59-65.

MARTINS, A.C.M., BERNARD, E., GREGORIN, R. \& SILVA, W.A.S., 2011. Filling data gaps on the diversity and distribution of Amazonian bats (Chiroptera): The case of Amapá, easternmost Brazil. Zoologia 28:177-185, http://dx.doi.org/10.1590/S198446702011000200004

MEDELLÍN, R.A., EQUIHUA, M. \& AMIN, M.A. 2000. Bat Diversity and Abundance as Indicators of Disturbance in Neotropics Rainforest. Conser. Biol. 14:1666-1675, http://dx.doi.org/ 10.1046/j.1523-1739.2000.99068.x

MUÑIZ-MIRET, N., VAMOS, R., HIRAOKA, M., MONTAGNINI, F. \& MENDELSOHN, R.O. 1996. The economic value of managing the açaí palm (Euterpe oleracea Mart.) in the floodplains of the Amazon estuary, Pará, Brazil. For. Ecol. Manage. 87: 163-173, http://dx.doi.org/10.1016/S0378-1127(96)03825-X

NOGUEIRA, M.R., LIMA, I.P., MORATELLI, R., V. DA C. TAVARES, V.C., R. GREGORIN, R \& PERACCHI, A.L. 2014. Checklist of Brazilian bats, with comments on original records. Check List. 10(4): 808-821, http://dx.doi.org/10.15560/10.4.808

OCHOA, J. \& VELAZCO, P. 2008. Glyphonycteris daviesi. In: IUCN 2014. IUCN Red List of Threatened Species. Version 2014.1. $<$ www.iucnredlist.org $>$. Downloaded on 14 June 2014

PAGLIA, A.P., FONSECA, G.A.B., RYLANDS, A.B., HERRMANN, G., AGUIAR, L.M.S., CHIARELlO, A.G., LEITE, Y.L.R., COSTA, L.P., SICILIANO, S., KIERULFF, C.M., MENDES, S.L., TAVARES, V.C., MITTERMEIER, R.A. \& PATTON, J.L. 
2012. Anoted List of Brazilian Mammals. 2nd version revised. Occasional Papers in Conservation Biology, The University of Chicago Press, Chicago.

PRANCE, G.T. 1979. Notes on vegetation of Amazonia III. The terminology of Amazonian forest types subject to inundation. Brittonia 31: 26-38.

PRESLEY, S.J., WILLIG, M.R., WUNDERLE, J.M. \& SALDANHA, L.N. 2008. Effects of reduced-impact logging and forest physiognomy on bat populations of lowland Amazonian forest. J. Appl. Ecol. 45: 14-25, http://dx.doi.org/10.1111/j.13652664.2007.01373.x

QUEIROZ, J.A.L. \& MOCHIUTTI, S. 2001. Plantio de açaizeiros. Embrapa Amapá Comunicado técnico n. 55, Macapá.

R DEVELOPMENT CORE TEAM. 2013. R: A Language and Environment for Statistical Computing. R Foundation for Statistical Computing, Vienna, Austria. URL http://www.R-project.org. ISBN 3-900051-07-0.

RAMOS PEREIRA, M.J., MARQUES, J.T. \& PALMEIRIM, J.M., 2010a. Ecological responses of frugivorous bats to seasonal fluctuation in fruit availability in Amazonian forests. Biotropica 42: 680-687

RAMOS PEREIRA, M.J, MARQUES, J.T \& PALMERIM, J.M. 2010b. Vertical stratification of bat assemblages in flooded and unflooded Amazonian forests. Curr. Zool. 56: 469-478.

RAMOS PEREIRA, M.J, MARQUES, J.T, SANTANA, J, SANTOS, C. D, VALSECCHI, J, QUEIROZ, H.L, BEJA, P \& PALMEIRIM, J. M. 2009. Structuring ofAmazonian bat assemblages: the roles of flooding patterns and floodwater nutrient load. J Anim Ecol 78: 11631171, http://dx.doi.org/10.1111/jae.2009.78.issue-6

SILVA, C.R., MARTINS, A.C.M., CASTRO, I.J., BERNARD, E., CARDOSO, E.M., LIMA, D.S., GREGORIN, R., ROSSI, R.V., PERCEQUILLO, A.R. \& CASTRO, K., C. 2013. Mammals of Amapá State, Eastern Brazilian Amazonia: a revised taxonomic list with comments on species distributions. Mammalia 77: 409-424, http://dx.doi.org/10.1515/mammalia-2012-0121

SILVEIRA, L.F., BEISIEGEL, B.D.M., CURCIO, F.F., VALDUJO, P.H., DIXO, M., VERDADE, V.K. \& CUNNINGHAM, P.T.M. 2010. Para que servem os inventários de fauna? Estud. av. 24, 173207, http://dx.doi.org/10.1590/S0103-40142010000100015

SIMMONS, N.B., \& VOSS, R.S. 1998. The Mammals of Paracou, French Guiana: A Neotropical lowland rainforest fauna. Part 1. Bats. Bull. Am. Mus. Nat. Hist. 237: 1-219.

SIOLI, H. 1984. The Amazon: Limnology and landscape ecology of a mighty tropical river and its basin. Dr. W. Junk Publishers,
Monographiae Biological, Vol. 56. Ed. Dumont, H.J., Dordrecht/ Boston.

SORIANO, P.J. \& OCHOA, J.G. 2001. The consequences of timber exploitation for bat communities in tropical America. In The cutting edge: conserving wildlife in logged tropical forests (Fimbel, R.A., Grajal, A. \& Robinson, J., Eds.). Columbia University Press, New York, pp. 153-166.

STRAUBE, F.C. \& BIANCONI, G.V. 2002. Sobre a grandeza e a unidade utilizada para estimar esforço de captura com utilização de redes-de-neblina. Chirop. Neotr. 8, 150-152.

SUDAM (Superintendência de Desenvolvimento da Amazônia). 1984. Atlas climatológico da Amazônia brasileira. Belém

TADDEI A.V., GONÇALVES C.A., PEDRO W.A., TADEI W.J., KOTAIT I. \& ARIETA, C. 1991. Distribuição do morcego vampiro Desmodus rotundus no Estado de São Paulo e a raiva dos animais domésticos. Coordenadoria de Assistência Técnica Integral, Campinas.

THOISY, B., PAVAN, A.C., DELAVAL, M., LAVERGNE, A., LUGLIA, T., PINEAU, K., RUEDI, M., RUFRAY, V. \& CATZEFLIS, F. 2014. Cryptic diversity in common mustached bats Pteronotus cf parnellii (Mormoopidae) in French Guiana and Brazilian Amapa. Acta Chiropt. 16 (1): 1-13, http://dx.doi.org/ 10.3161/150811014X683228

VOSS, R.S. \& EMMONS, L.H. 1996. Mammalian diversity in Neotropical lowland rainforest: a preliminary assessment. Bull. Am. Mus. Nat. Hist. 230: 1-115.

WEINSTEIN, S. \& MOEGENBURG, S. 2004. Açai Palm Management in the Amazon Estuary: Course for Conservation or Passage to Plantations? Conservat. Soc. 2: 315-346.

WILKINSON, G.S. 1985. The social organization of the common vampire bat. Behav. Ecol. Sociobiol. 17: 123-134.

WILLIAMS, S.L. \& GENOWAYS, H H. 2008. Subfamily Phyllostominae Gray, 1825. In Mammals of South America, Volume I. Marsupials, xenarthrans, shrews, and bats (A.L. Gardner, ed.). University of Chicago Press, Chicago and London, pp. 255-300.

WILLIG, M.R. 1986. Bat community struture in South America: a tenacious chimera. Rev. Chil. Hist. Nat. 59: 151-168.

WITTMANN, F., JUNK, W.J. \& SCHÖNGART, J. 2010. Phytogeography, species diversity, community structure and dynamics of central Amazonian floodplain forests. In Central Amazonian Floodplain Forests: Ecophysiology, Biodiversity and Sustainable Management (Junk, W. J., Piedade, M. T. F., Parolin, P., Wittmann, F. \& Schöngart, J., Eds.). Ecological Studies., vol 210 Springer Verlag, Heidelberg, pp. 61-102 